\title{
Indigenous Knowledge of Some Medicinal Plants of Himalaya Region, Dawarian Village, Neelum Valley, Azad Jammu and Kashmir, Pakistan
}

\author{
Khawaja Shafique Ahmad, ${ }^{1, *}$, Sadaf Habib ${ }^{2}$ \\ ${ }^{1}$ Department of Botany, University of Agriculture, Faisalabad \\ ${ }^{2}$ University of Chinese Academy of Sciences, Beijing \\ *Corresponding Author: khsahmad@yahoo.com
}

Copyright (C 2014 Horizon Research Publishing All rights reserved.

\begin{abstract}
Investigation and documentation of the status of medicinal plants and associated knowledge was conducted in village Dawarian, Neelum valley AJ\&K. A total of 59 plant species were used for furteen (14) different categories of diseases. The medicinal plants were economically used in treating a certain ailments, such as skin diseases (10spp., $14.49 \%$ ) followed by headache \& fever, cough \& flu (8spp., $11.59 \%$ each), stomach problems \& asthma (7spp., $10.14 \%$ each), jaundice \& dysentery (5spp., $7.25 \%$ each), bronchitis (4spp., 5.80\%), diabetics, rheumatic pain, bone fracture \& wound healing (3spp., $4.35 \%$ ), ulcer (2spp., $5.10 \%$ each) and dandruff (1spp., 1.45\% ). The highest value of Informant consensus factor (ICF) is 0.71 for diabetics and lowest value is for bronchitis $0.21 \%$ whereas, Berberis lycium and Ajuga bracteosa has the highest fidelity level (FL: 100\%) being used to cure diabetic patients. Direct Matrix Ranking (DMR) results showed that Juglan regia stands first in being the most multipurpose medicinal plant, followed by Morus alba whereas, Aconitum heterophyllum was found most threatened plant in the study area. Timber mafia/export was the leading threat followed by construction, fuel, grazing and urbanization respectively. Medicinal flora such as, Berberis lyceum, Ajuga bracteosa, Aconitum heterophyllum, Bistorta amplexicaule, Saussurea lapa and Jurinea dolomiaea are on the edge of extinction due to over exploitation.
\end{abstract}

Keywords Ethnobotany, Threat Assessment, Dawarian, Neelum Valley, AJ\&K

\section{Introduction}

Indigenous knowledge has been significant in sourcing of medical remedies and development of commercial products. Recently, focus in ethnobotanical research has intensified on medicinal, cultural and commercial/livelihoods ethnobotany (Hossan et al., 2010). Ethnobotany is a broad term used to the study the direct interrelations between man and plants
(Balick and Cox, 1996). The reliance of human beings on plants for their livelihoods is mandatory and it is primarily started by domestication and dates back to 10,000 years (Martin, 1995). Ethnobotanical study documents the facts on cultural interaction of people with plants. It also tries to find out how local people have traditionally used plants for various purposes and how they integrated plants into their cultural tradition and religion (Balick and Cox, 1996).

The focus of ethnobotany is on how plants have been or are used, managed and perceived in human societies and includes plants used for food, medicine, rituals, social life and others. The relationship between plants and human cultures is not limited to the use of plants for food, clothing and shelter but also includes their use for religious ceremonies, ornamentation and health care (Khan et al., 2008). The indigenous knowledge of plants has been communicated from generation after generation through oral message and individual experience (Shinwari, 2010).

In developing countries, use of indigenous plants by local people for their day ailments is common practice because western based health care system is inefficient due to poor staffing or because western drugs are expensive (Mahmood et al., 2011). Ethnomedicine is the system to maintain health and treat diseases based on folk beliefs and traditional knowledge, skills, methods and practices. This knowledge is disappearing because of rapid scientific, ecological and socio-economic changes. Therefore, ethnomedicinal knowledge must be acknowledged and conserved in a systematic way (Mohammed et al., 2006).

In Pakistan $60 \%$ of population especially in the villages are taking health cares by traditional practitioners who recommend herbal prescriptions (Haq, 1983). It is reported that $80 \%$ of the African population is depended on the traditional medicines (WHO, 2002). In Pakistan almost 80\% of endemic plants are restricted to the northern and western mountains (Ali \& Qaiser, 1986). Azad Jammu and Kashmir $(A J \& K)$ is gifted with rich diversity medicinal plants. Many studies have been reported on the traditional medicinal uses 
of plants by the local communities of AJ\&K (Ishtiaq et al., 2012; Mahmood et al., 2011; Qureshi et al., 2007; Ishtiaq et al., 2006; Dar, 2003). The present study is focused on the important plant resources and their indigenous uses from the Dawarian, Neelum valley, AJ\&K, Pakistan.

\section{Materials and Methods}

\subsection{The Study Area}

The Neelum Valley is situated north-east of Muzaffarabad at an altitude of 900-6325 meters above sea level (a.s.1). It lies between $73^{\circ}-75^{\circ} \mathrm{E}$ longitude and $32^{\circ}-35^{\circ} \mathrm{N}$ latitude (Mahmood et al., 2011; Ahmad et al., 2012b). It is the largest district of Azad Kashmir covering an area of $3737 \mathrm{~km}^{2}$ (Fig 1). Dawarian village is situated at $110 \mathrm{~km}$ north of the capital Muzaffarabad and is about $5450 \mathrm{ft}$ above sea level (a.s.1). This mountain based area is excellent for adventure tourism and unique customs and way of living. The climate is temperate with very cold winters (average $0-4{ }^{\circ} \mathrm{C}$ ) and moderate summers (average temperature $20-30^{\circ} \mathrm{C}$ ). Average rainfall is $165 \mathrm{~cm}$ annually. The area has various types of landforms and small plateaus. Soil is loamy and sandy loam, capable of retaining moisture and good growth of forests. Majority of the area is covered with thick vegetation and forest trees (Dar, 2003).

\subsection{Data Collection}

Many field trips were arranged and the area was thoroughly surveyed for the documentation of folk knowledge. Standard methods such as open-ended and close-ended interview were used for collection of plant materials. One hundred informants were randomly selected interview. The plant specimens collected, pressed, dried, preserved and were arranged alphabetically by family name, vernacular name and ethnomedicinal uses. The collected specimens were identified with the help of floristic literature (Nasir \& Ali, 1970-1989; Ali \& Nasir, 1990-1991; Ali \& Qaiser, 2001-2008; Qureshi, 2004).

\subsection{Data Analysis}

Data was tested through statistical methods to obtain results from the observations and data collected from the study area. Information consensus factor (ICF) was calculated for each category to identify the agreement of the informants on the reported cure. ICF was calculated by equation $[\mathrm{ICF}=$ nur-nt/nur-1] where Nur= number of use citation in each category and $\mathrm{Nt}=$ number of species used. The fidelity level (FL), the percentage of informants claiming the use of a certain plant for the same major purpose, was calculated by, $\left[\mathrm{Np} / \mathrm{N}^{*} 100\right]$. Where $\mathrm{Np}=$ number of informants that claim a use of a plant species for a particular use and $\mathrm{N}=$ number of informants that use the plants. Such methods are helpful in the selection of plants for further studies (Alexiades, 1996). Direct matrix ranking was conducted following Cotton (1996) for 7 multifarious medicinal plants commonly reported by informants. Preference ranking and threat to medicinal plants were also determined (Alexiades, 1996).

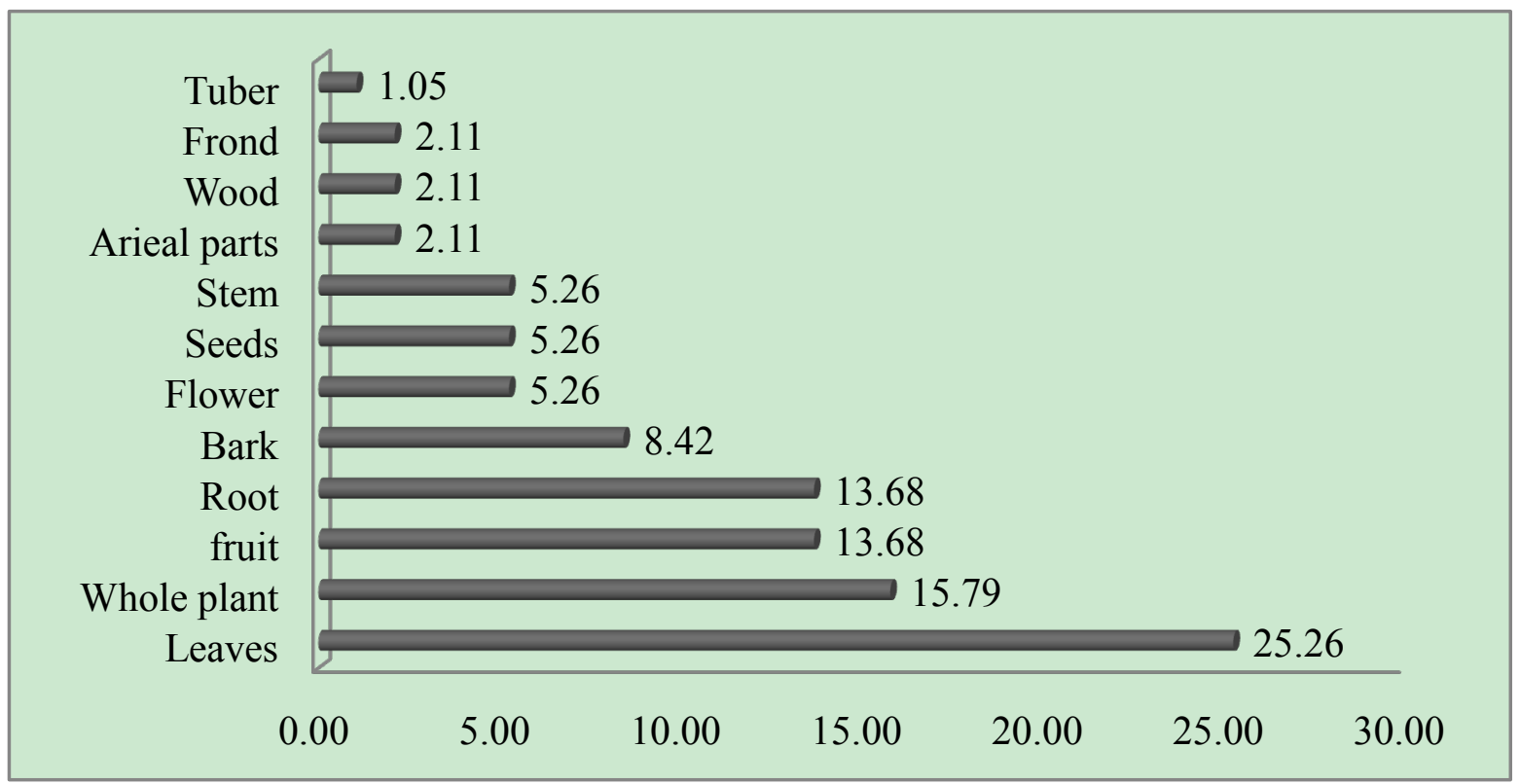

Figure1. Parts percentage of plants used for different purposes 


\section{Results and Discussion}

Many studies have been conducted on the indigenous uses of medicinal plants in Pakistan and Azad Kashmir (Ahmad et al., 2012a; Ahmad et al., 2012b; Ishtiaq et al., 2012; Shinwari and Qaiser, 2011; Mahmood et al., 2011; Shinwari, 2010; Ishtiaq et al., 2007; Ishtiaq et al., 2006; Hamayun et al., 2006; Shinwari \& Gilani, 2003). Shinwari \& Gilani (2003) and Hamayun et al., (2006) describe indigenous knowledge of medicinal plants from northern areas of Pakistan. Ali \& Qaisar (2009) reported 83 taxa that were used locally in Chitral district of Hindukush range. Astragalus, the largest genus in Pakistan has about 134 species. A sum of 59 plant species belonging to 52 genera and 35 families were collected from research area. Information regarding their botanical name, vernacular name, family, part used and their ethno medicinal uses are listed in the Check List. Asteraceae was most dominating family in the study area $(8$ spp., 13.56\%) followed by Rosaceace (4 spp., 6.78\%; Table 1). Leaves were highly utilized part (24spp., 25.26\%) followed by whole plant (18spp., 19.15\%), fruits and roots (13spp., 13.68\% each), bark (8spp., 8.42\%), seeds, flower and stem (5spp., 5.26\% each), aerial parts, wood and frond (2spp., 2.11\%) and tuber (1spp., 1.05\%) (Fig 1). A total of 14 different categories of diseases have been studied during the survey of selected area (Fig 2). The medicinal plants were efficiently used in treating a certain disease, such as skin diseases (10spp., 14.49\%) followed by headache \& fever, cough \& flu (8spp., $11.59 \%$ each), stomach problems \& asthma (7spp., $10.14 \%$ each), jaundice \& dysentery (5spp., $7.25 \%$ each), bronchitis (4spp., 5.80\%), diabetics, rheumatic pain, bone fracture \& wound healing (3spp., $4.35 \%$ ), ulcer (2spp., 5.10\% each) and dandruff (1spp., $1.45 \%$ ). Bokhari (1994) documented the vegetation analysis of Machyara National Park Muzaffarabad AJ\&K and reported 10 plant communities in different regions of the National Park. Ethnobotany of Lawat and its allied areas District Muzafarabad was reported which provided a checklist of 52 species. Out of which, 3 species are of Gymnospermic families while 49 species are of Angiospermic families (Dar, 2003).

Table 1. Folk medicinal uses of plants of Neelum valley AJ\&K

\begin{tabular}{|c|c|c|c|c|c|}
\hline S.No & Botanical Name & Local Name & Family & $\begin{array}{c}\text { Part (s) } \\
\text { used }\end{array}$ & Folk medicinal Uses \\
\hline 1 & Adiantum capillus-veneris $\mathrm{L}$. & Sumbal & Adiantaceae & $\mathrm{Fr}$ & Fruit past is used in skin diseases, fever and cough. \\
\hline 2 & Adiantum incisum Forssk. & Kakva & Adiantaceae & Fr & $\begin{array}{l}\text { A paste made from the rhizomes is applied to treat } \\
\text { cuts and wounds. The paste of rhizome is applied } \\
\text { as a remedy for conditioning of hair and scalp. }\end{array}$ \\
\hline 3 & Achyranthus aspera $\mathrm{L}$. & Puthkanda & Amaranthaceae & $\mathrm{Fr}$ & $\begin{array}{l}\text { A thin paste is obtained by grinding fresh roots } \\
\text { with sufficient quantity of water in a mortar and } \\
\text { pastel. The paste is applied to external genitalia. }\end{array}$ \\
\hline 4 & Amaranthus spinosus L. & $\begin{array}{l}\text { Surukh } \\
\text { ghanyar }\end{array}$ & Amaranthaceae & Ap & $\begin{array}{l}\text { Seeds are cooked with rice and are given in joint } \\
\text { pain. }\end{array}$ \\
\hline 5 & Anethum graveolens $\mathrm{L}$. & Soya & Apiaceae & $\mathrm{Fr}$ & $\begin{array}{l}\text { Leaves are cooked as vegetable and also used as } \\
\text { flavouring in salads. Powdered fruit is given in } \\
\text { cough, asthma, fever, ulcer and skin allergies. }\end{array}$ \\
\hline 6 & Achillea millefolium $\mathrm{L}$. & Sultani booti & Asteraceae & $\mathrm{L}$ & $\begin{array}{c}\text { Leaves are chewed to treat toothache. The juice of } \\
\text { leaves is poured in ear to treat earache. Tea made } \\
\text { from the plant is used to treat T.B., stomach } \\
\text { disorder and fever. }\end{array}$ \\
\hline 7 & Anaphalis nepalensis Spreng. & Paharee jaree & Asteraceae & Wp & $\begin{array}{c}\text { The juice of the plant and is applied on joint pain. } \\
\text { The same is applied to prevent skin from sun } \\
\text { burning. }\end{array}$ \\
\hline 8 & Saussurea lanceolata Clarke. & Kuth & Asteraceae & $\mathrm{R}, \mathrm{L}, \mathrm{Fl}$ & $\begin{array}{l}\text { The paste of roots is externally applied on skin } \\
\text { allergies and pimples. Decoction of roots is used to } \\
\text { cure stomach pain and typhoid fever. }\end{array}$ \\
\hline 9 & Jurinea dolomiaea Boiss. & Guggal toof & Asteraceae & $\mathrm{R}$ & $\begin{array}{l}\text { The extract of roots is used as tonic for weakness } \\
\text { of the bones. It is cooked with maize flour and is } \\
\text { used for the treatment of internal fractures. }\end{array}$ \\
\hline 10 & $\begin{array}{c}\text { Taraxacum officinale Weber et } \\
\text { Wigg. }\end{array}$ & Hand & Asteraceae & $\mathrm{L}, \mathrm{R}$ & Leaves are used as vegetables to treat jaundice. \\
\hline 11 & Artemisia scoparia Waldst \& Kit. & Ghass & Asteraceae & St, L & $\begin{array}{l}\text { The plant antibacterial, stomachic, anthelmintic } \\
\text { and purgative. It is also used as fodder. }\end{array}$ \\
\hline 12 & $\begin{array}{l}\text { Conyza canadensis (L.) } \\
\text { Cronquist. }\end{array}$ & Kutahudy & Asteraceae & Wp & $\begin{array}{l}\text { The plant is homeostatic, stimulant, astringent and } \\
\text { diuretic. Young leaves and seedlings are cooked in } \\
\text { rice. }\end{array}$ \\
\hline 13 & Sonchus asper (L.)Hill. & Dodak & Asteraceae & $\mathrm{Wp}$ & Young leaves and stem are cooked as vegetable. \\
\hline 14 & Betula utilis D.Don. & Borzal & Betulaceae & B & $\begin{array}{c}\text { The bark is soaked in water and few drop poured in } \\
\text { ear to treat earache. The same is used to wash } \\
\text { chronic wounds. The powder of bark is given in } \\
\text { jaundice. }\end{array}$ \\
\hline
\end{tabular}




\begin{tabular}{|c|c|c|c|c|c|}
\hline 15 & Berberis lycium Royle & Sumbal & Berberidaceae & $\mathrm{B}, \mathrm{R}$ & $\begin{array}{l}\text { The paste of bark and roots is applied externally to } \\
\text { treat fracture and headache. Locally the dried root } \\
\text { is mixed with egg and fried in cow's ghee and used } \\
\text { for the treatment of fractured bones and wounds } \\
\text { healing. The same is internally given as general } \\
\text { body tonic. }\end{array}$ \\
\hline 16 & $\begin{array}{l}\text { Cynoglossum lanceolatum } \\
\text { Forssk. }\end{array}$ & Landi & Broginaceae & $\mathrm{Wp}$ & $\begin{array}{l}\text { The past of leave is applied on abscess to remove } \\
\text { pus. }\end{array}$ \\
\hline 17 & Onosma bracteatum Wall. & Gaozaban & Broginaceae & $\mathrm{Wp}$ & $\begin{array}{c}\text { Powder of root is used in asthma and bronchitis. } \\
\text { Decoction of leave is given in stomach and bladder } \\
\text { irritation. }\end{array}$ \\
\hline 18 & Brassica compestris $\mathrm{L}$. & Sarryan & Brasicaceae & Fl & $\begin{array}{l}\text { Leaves and roots are commonly used as vegetable } \\
\text { acting as digestive. }\end{array}$ \\
\hline 19 & Canabus sativa $\mathrm{L}$. & Bhung & Canabinaceae & $\mathrm{L}, \mathrm{Fl}$ & $\begin{array}{c}\text { The powder of leaves is used in abdominal } \\
\text { disorders and diarrhea. }\end{array}$ \\
\hline 20 & Viburnum cotinifolium D. Don & Guchh & Caprifoliaceae & $\mathrm{Fr}, \mathrm{L}$ & The flower and leaves are sedative and astringent. \\
\hline 21 & Silene apetala Willd. & But Karam & $\begin{array}{c}\text { Caryophylacea } \\
\mathrm{e}\end{array}$ & $\mathrm{L}, \mathrm{St}$ & $\begin{array}{l}\text { Leaves are emollient. The plant is used as fodder } \\
\text { for cattle. }\end{array}$ \\
\hline 22 & Cucumis sativus $\mathrm{L}$. & Kheera & Cucurbitaceae & $\mathrm{Fr}, \mathrm{Sd}$ & $\begin{array}{l}\text { Fruit is used in salad as cooling agent. Powder of } \\
\text { seed is used as digestive. }\end{array}$ \\
\hline 23 & Dioscorea bulbifera Decne. & Contrees & Dioscoreaceae & $\mathrm{L}, \mathrm{St}, \mathrm{Tu}$ & $\begin{array}{l}\text { The leaf juice is used to treat snakebites and } \\
\text { scorpion stings. The powder of tuber is given in } \\
\text { dysentery and piles. The fern is also used in the } \\
\text { production of sex hormones }\end{array}$ \\
\hline 24 & Dryopteris ramosa (Hope) & Longur & $\begin{array}{c}\text { Dryopteridacea } \\
\mathrm{e}\end{array}$ & St, L & $\begin{array}{l}\text { The juice of the plant is given in stomach pain. } \\
\text { Fronds are used as fodder for the horses. }\end{array}$ \\
\hline 25 & Dryopteris stewartii Fraser. Jenk & Dad & $\begin{array}{c}\text { Dryopteridacea } \\
\mathrm{e}\end{array}$ & $\mathrm{Wp}$ & $\begin{array}{l}\text { Soft and fresh branches are boiled and used as } \\
\text { vegetable. }\end{array}$ \\
\hline 26 & Diospyros lotus $\mathrm{L}$. & Amlok & Ebenaceae & Fr & $\begin{array}{l}\text { The juice of unripe fruits given to lower the blood } \\
\text { pressure. The fruit is used as a remedy for } \\
\text { hiccough. }\end{array}$ \\
\hline 27 & Ricinus comunis $\mathrm{L}$. & Arind & Euphorbiaceae & $\mathrm{Sd}, \mathrm{L}$ & $\begin{array}{l}\text { Castor oil is given in constipation before and after } \\
\text { child birth to mother. The same is given to infants } \\
\text { to remove constipation. Paste of leaves is slightly } \\
\text { warmed over fire and applied on rheumatic pain } \\
\text { and injuries. }\end{array}$ \\
\hline 28 & Phaseolus lunatus L. & Moth & Fabaceae & $\mathrm{Sd}$ & $\begin{array}{l}\text { Powder of seed is used in fever and is good source } \\
\text { of food. The dried seeds are cooked with rice and } \\
\text { given to fever patients. }\end{array}$ \\
\hline 29 & Trigonella foenum-graceum $\mathrm{L}$. & Methi & Fabaceae & $\mathrm{Wp}$ & $\begin{array}{l}\text { Seeds are chewed and swallowed with salad water } \\
\text { for indigestion. The powder of the plant is given in } \\
\text { diabetes. }\end{array}$ \\
\hline 30 & Trifolium repens L. & Sinja & Fabaceae & $\mathrm{Wp}$ & $\begin{array}{l}\text { Seeds are chewed and swallowed with water to } \\
\text { relief abdominal pain. }\end{array}$ \\
\hline 31 & $\begin{array}{c}\text { Indigofera heterantha Wall. ex } \\
\text { Brandis. }\end{array}$ & Kanthi & Fagaceae & $\mathrm{Wp}$ & $\begin{array}{l}\text { Leaves are rubbed on skin allergy. Leaves are } \\
\text { given to cattle to treat dysentery. }\end{array}$ \\
\hline 32 & Quercus incana A. Camus. & Reen & Fagaceae & B & $\begin{array}{l}\text { The decoction of the bark prepared is given to treat } \\
\text { throat pain and tonsillitis. The same is also used in } \\
\text { diarrhea, dysentery and rectal bleeding. Galls are } \\
\text { used in small quantity as alternate to bark. }\end{array}$ \\
\hline 33 & Geranium wallichianum D. Don & Ratanjog & Geraniaceae & $\mathrm{R}$ & $\begin{array}{c}\text { Powder of dried root is doted on wounds. Leaves } \\
\text { extract is given in vision problem. }\end{array}$ \\
\hline 34 & Morchella esculenta Fries & Gujai & Helveliaceae & $\mathrm{Wp}$ & $\begin{array}{l}\text { Whole plant is given for general body tonic, joins } \\
\text { aches or potency, insomnia and poor appetite. }\end{array}$ \\
\hline 35 & $\begin{array}{c}\text { Aesiculus indica Wall. ex. Comb } \\
\text { (Hook) }\end{array}$ & Bankkor & $\begin{array}{l}\text { Hippocastanac } \\
\text { eae }\end{array}$ & $\mathrm{L}$ & $\begin{array}{l}\text { Fruits are given to horses in colic pain. Oil } \\
\text { obtained from the seed is externally applied in } \\
\text { rheumatic pains. }\end{array}$ \\
\hline 36 & Juglans regia $\mathrm{L}$. & Khoor & Juglandaceae & $\mathrm{L}, \mathrm{B}, \mathrm{Fr}$ & $\begin{array}{l}\text { The ripened fruit is used as a brain tonic. The } \\
\text { bark of stem and root is used for cleansing teeth } \\
\text { and gums. The wood is used as fuel source. }\end{array}$ \\
\hline 37 & Ajuga bracteosa Wall. ex Benth. & Jane adam & Lamiaceae & $\mathrm{Wp}$ & $\begin{array}{l}\text { Paste of the leaves is applied to cure headache. The } \\
\text { powder of the whole plant is given to treat } \\
\text { abdominal pain and indigestion. }\end{array}$ \\
\hline 38 & Mentha arvensis $\mathrm{L}$. & Podina & Lamiaceae & $\mathrm{Wp}$ & $\begin{array}{l}\text { The plant along with lemon grass is boiled in water } \\
\text { to obtain extract that is given in fever. The plant is } \\
\text { mixed with funnel seeds and boiled in water }\end{array}$ \\
\hline
\end{tabular}




\begin{tabular}{|c|c|c|c|c|c|}
\hline & & & & & $\begin{array}{l}\text { (Foeniculum vulgare) which is given in diarrhea, } \\
\text { vomiting and cholera. }\end{array}$ \\
\hline 39 & $\begin{array}{l}\text { Plectranthus rugosus Wall. ex } \\
\text { Benth. }\end{array}$ & Peemar & Lamiaceae & $\mathrm{Wp}$ & $\begin{array}{l}\text { Past of roots and leaves is used in burning } \\
\text { sensation, leprosy and skin disease. The juice of } \\
\text { leaves is given in vomiting and diarrhea. }\end{array}$ \\
\hline 40 & Acacia nilotica Willd. & Kiker & Mimosaceae & $\mathrm{L}, \mathrm{B}$ & $\begin{array}{l}\text { Bark decoction used as a gargle in sore threat and } \\
\text { toothache. Foliage and pods used as fodder. Wood } \\
\text { is used as timber, agricultural implements and fuel } \\
\text { wood source. }\end{array}$ \\
\hline 41 & Morus alba L. & Safed toot & Moraceae & $\begin{array}{l}\mathrm{R}, \mathrm{B}, \mathrm{Fr} \\
\mathrm{L}\end{array}$ & $\begin{array}{c}\text { Roots bark is used in toothache and cough. Leaves } \\
\text { are boiled in water and given to treat fever, sore } \\
\text { threat and headache. }\end{array}$ \\
\hline 42 & Morus nigra L. & Kala toot & Moraceae & $\mathrm{Fr}$ & $\begin{array}{l}\text { The syrup is made from fruit pulp and given in } \\
\text { anemia and sore throat. }\end{array}$ \\
\hline 43 & Olea ferruginea Royle & Rons pattar & Oleaceae & Wp & $\begin{array}{c}\text { Leaves past are used to cure wounds and ulcer. } \\
\text { The paste of leaves is applied in healing fractured } \\
\text { bones. }\end{array}$ \\
\hline 44 & Plantago major $\mathrm{L}$. & Asphagol & Plantaginaceae & $\mathrm{Wp}$ & $\begin{array}{l}\text { Powder of leaves is given in abdominal pain and } \\
\text { indigestion. Dry seeds soaked in water are given in } \\
\text { dysentery to cure. The paste of tuber is used as } \\
\text { antidandruff agent. }\end{array}$ \\
\hline 45 & Plantago ovata Forssk. & $\begin{array}{l}\text { Chamchi } \\
\text { pattar }\end{array}$ & Plantaginaceae & $\mathrm{Sd}$ & $\begin{array}{l}\text { Powder of dried seeds is given in constipation, } \\
\text { chronic, diarrhea, dysentery. Paste of seed applied } \\
\text { on burning areas to relieve. }\end{array}$ \\
\hline 46 & $\begin{array}{l}\text { Bistorta amplexicaulis (D.Don) } \\
\text { Greene } \\
\end{array}$ & Masloon & Polygonaceae & $\mathrm{R}, \mathrm{L}$ & $\begin{array}{c}\text { Dried roots are used in making tea. The } \\
\text { herbaceous roots are also used as fodder to cattle. }\end{array}$ \\
\hline 47 & Rumax nepalense Spreng. & Holla & Polygonaceae & L, St, R & $\begin{array}{l}\text { Leaves are cooked as vegetable and given to } \\
\text { pregnant to treat constipation. Stem and leaves } \\
\text { extract is applied on wounds to stop bleeding. }\end{array}$ \\
\hline 48 & Punica granatum $\mathrm{L}$. & Anar & Punicaceae & Wp & $\begin{array}{l}\text { The bark and seeds are used in bronchitis. The ripe } \\
\text { fruit is used as tonic. }\end{array}$ \\
\hline 49 & $\begin{array}{c}\text { Aconitum heterophyllum Wall ex. } \\
\text { Royle }\end{array}$ & Ptrees & Ranunculaceae & $\mathrm{R}$ & $\begin{array}{c}\text { Root is boiled with milk and used for the treatment } \\
\text { of fever, flu cough and abdominal pain. Roots are } \\
\text { also used for dysentery, cirrhoses, fever, and } \\
\text { vomiting and stomach disorder. }\end{array}$ \\
\hline 50 & Actaea spicata $\mathrm{L}$. & Rech dad & Ranunculaceae & R, L, Fr & $\begin{array}{l}\text { Dried powder of leaves is used as insecticide. Oil } \\
\text { obtained from roots is given as tonic. }\end{array}$ \\
\hline 51 & Aquilegia flavescens Watson. & Zaban posh & Ranunculaceae & $\mathrm{L}, \mathrm{R}$ & $\begin{array}{l}\text { Powder of roots and leaves is given in fever. The } \\
\text { paste of seed is applied to get rid lice from the hair. }\end{array}$ \\
\hline 52 & Prunus avium $\mathrm{L}$. & Glass & Rosaceace & Wd, Fr, L & Leaves are used as fodder. Wood is used as fuel. \\
\hline 53 & Prunus bokharensis Royle & Alobukhara & Rosaceace & $\begin{array}{l}\mathrm{B}, \mathrm{L}, \mathrm{Fl} \\
\mathrm{Fr}\end{array}$ & $\begin{array}{l}\text { Paste of fresh leaf and stem bark is applied } \\
\text { externally on wounds. }\end{array}$ \\
\hline 54 & Prunus persica Stokes. & Aroo & Rosaceace & $\mathrm{Fr}$ & $\begin{array}{l}\text { Fruit is eaten by diabetic patients. It is also useful } \\
\text { in rheumatic pain. }\end{array}$ \\
\hline 55 & Prunus domestica $\mathrm{L}$. & Alocha & Rosaceace & Fr, L & $\begin{array}{l}\text { The fruit of plant is laxative and used in treating } \\
\text { constipation. }\end{array}$ \\
\hline 56 & Salix tetrasperma Roxb. & Beensa & Salicaceae & $\mathrm{B}, \mathrm{L}, \mathrm{Wd}$ & $\begin{array}{l}\text { Wood is used as making sport articles like cricket } \\
\text { balls. It is also used as fuel and foliage as fodder. }\end{array}$ \\
\hline 57 & Urtica dioica $\mathrm{L}$. & Kairy & Urticaceae & $\mathrm{R}, \mathrm{Ap}$ & $\begin{array}{c}\text { Young leaves are cooked as a potherb and added to } \\
\text { soups. They can also be dried for winter use. } \\
\text { Decoction of root is given to increase milk } \\
\text { secretion and reduces prostate enlargement. The } \\
\text { decoction of plant is applied on baldness and } \\
\text { dandruff. }\end{array}$ \\
\hline 58 & Viola canescens Wall. ex Roxb. & Banafsha & violaceae & $\mathrm{Sd}, \mathrm{R}, \mathrm{L}$ & $\begin{array}{l}\text { The decoction of leaves and flowers is given } \\
\text { internally in the treatment of bronchitis, } \\
\text { respiratory catarrh, coughs and asthma to treat. } \\
\text { The same is used as gargle to treat mouth and } \\
\text { throat infections. }\end{array}$ \\
\hline 59 & Vitis vinifera $\mathrm{L}$. & Dakh & Vitaceae & $\mathrm{Fr}, \mathrm{L}, \mathrm{Fl}$ & $\begin{array}{l}\text { Fruit is used as tonic and in relieving constipation. } \\
\text { Flowers are used in bronchitis and anemia. }\end{array}$ \\
\hline
\end{tabular}

Key: $\mathrm{B}=$ Bark, $\mathrm{Fl}=$ Flowers, $\mathrm{Fr}=$ Fruits, $\mathrm{L}=$ Leaves, $\mathrm{R}=$ Roots, $\mathrm{Sd}=\mathrm{Seeds}, \mathrm{Wp}=$ Whole plant, $\mathrm{Wd}=$ Wood, Ap=Arial parts, Fr=Fronds, $\mathrm{Tu}=\mathrm{Tubers}, \mathrm{St}=\mathrm{Stem}$. 


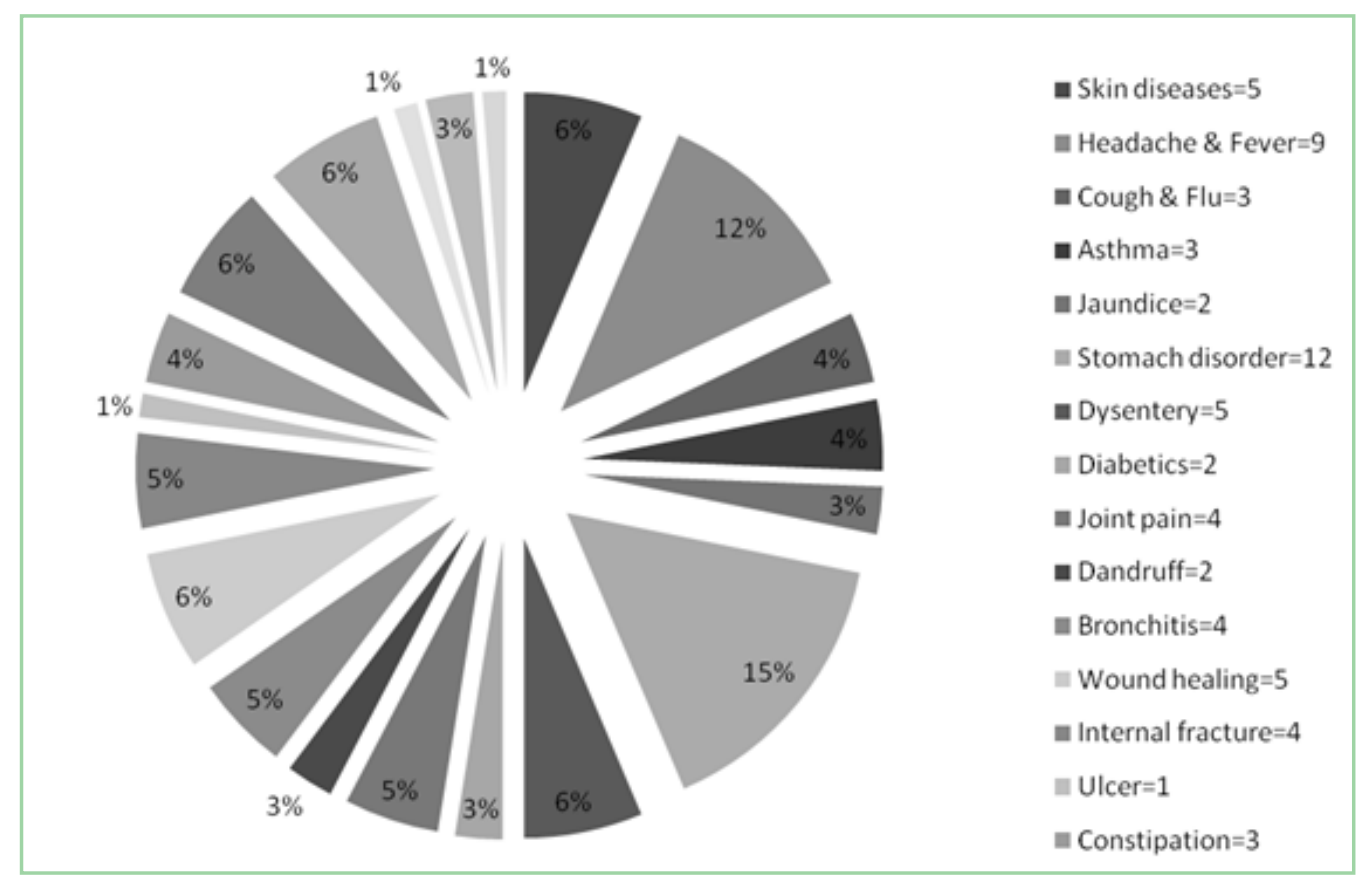

Figure 2. No. of plants used for the treatment of different diseases

Table 2. Informant Consensus Factor (ICF) by categories of diseases in the study area

\begin{tabular}{|cccc|}
\hline Categories & Species & Use citation & ICF (\%) \\
\hline Skin diseases & 10 & 27 & 0.65 \\
\hline Fever & 8 & 22 & 0.67 \\
\hline Cough & 8 & 17 & 0.62 \\
\hline Asthma & 7 & 19 & 0.67 \\
\hline Jaundice & 5 & 9 & 0.5 \\
\hline $\begin{array}{c}\text { Stomach } \\
\text { problems }\end{array}$ & 7 & 25 & 0.75 \\
\hline Dysentery & 5 & 10 & 0.5 \\
\hline Diabetics & 3 & 8 & 0.71 \\
\hline Rheumatic pain & 3 & 5 & 0.03 \\
\hline Dandruff & 1 & 1 & 0.5 \\
\hline Bronchitis & 4 & 3 & 0.1 \\
\hline Wound healing & 3 & 7 & 0.66 \\
\hline Bone fracture & 3 & 6 & 0.6 \\
\hline Ulcer & 2 & 5 & 0.7 \\
\hline
\end{tabular}

Table 3. Fidelity Level (FL) values of medicinal plants of the study area

\begin{tabular}{|cc|}
\hline Species & $\begin{array}{c}\text { Fidelity level (Fidelity) } \\
(\%)\end{array}$ \\
\hline Berberis lycium Royle & 100 \\
\hline Ajuga bracteosa Wall. ex Benth. & 100 \\
\hline Punica granatum L. & 95 \\
\hline Bistorta amplexicaulis (D.Don) Greene & 88 \\
\hline Morchella esculenta L. & 66 \\
\hline Juglans regia L. & 49 \\
\hline Plantago major L. & 75 \\
\hline Betula utilis D.Don & 37 \\
\hline Acacia nilotica Willd. & 34 \\
\hline Olea ferruginea Royle & 26 \\
\hline Morus nigra L. & 18 \\
\hline Plantago ovata Forssk. & 19 \\
\hline Viola canescens Wall. ex Roxb. & 14 \\
\hline
\end{tabular}

Table 4. Direct Matrix Ranking (DMR) of plant species with different uses other than medicinal value (total score of 10 informants) in the study area

\begin{tabular}{|cccccccc|}
\hline Uses & $\begin{array}{c}\text { Juglans } \\
\text { regia }\end{array}$ & $\begin{array}{c}\text { Ajuga } \\
\text { bracteosa }\end{array}$ & $\begin{array}{c}\text { Saussurea } \\
\text { lappa }\end{array}$ & $\begin{array}{c}\text { Berberis } \\
\text { lycium }\end{array}$ & $\begin{array}{c}\text { Morus } \\
\text { alba }\end{array}$ & $\begin{array}{c}\text { Ricinus } \\
\text { comunis }\end{array}$ & $\begin{array}{c}\text { Aconitum } \\
\text { heterophyllum }\end{array}$ \\
\hline Medicinal & 6 & 9 & 10 & 8 & 7 & 7 & 10 \\
\hline Fodder & 5 & 2 & 2 & 0 & 5 & 0 & 0 \\
\hline Fuel & 4 & 0 & 0 & 5 & 4 & 0 & 0 \\
\hline Construction & 4 & 0 & 0 & 0 & 3 & 0 & 0 \\
\hline Furniture & 5 & 0 & 0 & 0 & 3 & 0 & 0 \\
\hline Roof thatching & 4 & 0 & 0 & 0 & 2 & 0 & 10 \\
\hline Total & 28 & 11 & 12 & 13 & 24 & 7 & 6 th \\
\hline Rank & $1 \mathrm{st}$ & 5 th & 4th & 3rd & 2nd & 7 th & 0 \\
\hline
\end{tabular}


Table 5. Threatened plant species in the study area

\begin{tabular}{|c|c|c|c|c|c|c|c|c|c|c|c|c|}
\hline \multirow{2}{*}{ Threatened Plants } & \multicolumn{12}{|c|}{ Informants } \\
\hline & 1 & 2 & 3 & 4 & 5 & 6 & 7 & 8 & 9 & 10 & Total & Rank \\
\hline Aconitum heterophyllum & 4 & 3 & 3 & 4 & 4 & 5 & 5 & 4 & 5 & 4 & 41 & 1 st \\
\hline Bistorta amplexicaulis & 3 & 1 & 2 & 2 & 3 & 4 & 5 & 3 & 1 & 2 & 26 & 7th \\
\hline Ajuga bracteosa & 2 & 1 & 3 & 4 & 5 & 4 & 2 & 3 & 3 & 2 & 29 & 6th \\
\hline Saussurea lanceolata & 5 & 3 & 4 & 4 & 3 & 4 & 5 & 4 & 4 & 3 & 39 & 2nd \\
\hline Betula utilis & 4 & 3 & 5 & 3 & 2 & 4 & 3 & 4 & 3 & 3 & 34 & 4 th \\
\hline Geranium wallichianum & 3 & 5 & 4 & 3 & 5 & 4 & 4 & 2 & 3 & 3 & 36 & $3 \mathrm{rd}$ \\
\hline Dioscorea bulbifera & 4 & 3 & 3 & 2 & 3 & 2 & 2 & 5 & 3 & 3 & 30 & 5 th \\
\hline
\end{tabular}

Table 6. Priority Ranking (PR) of factors perceived as threats to plant biodiversity based on their level of destructive effects in the study area

\begin{tabular}{|c|c|c|c|c|c|c|c|c|c|}
\hline \multirow[t]{2}{*}{ Threats } & \multicolumn{6}{|c|}{ Respondent (R1-R6) } & \multirow[t]{2}{*}{ Total } & \multirow[t]{2}{*}{ Percentage (\%) } & \multirow[t]{2}{*}{ Rank } \\
\hline & $\mathrm{R} 1$ & $\mathrm{R} 2$ & R3 & R4 & R5 & R6 & & & \\
\hline Construction & 6 & 4 & 5 & 5 & 6 & 4 & 30 & 19.74 & $2 \mathrm{nd}$ \\
\hline Grazing & 2 & 5 & 4 & 6 & 4 & 6 & 27 & 17.76 & 4 th \\
\hline Timber mafia/export & 6 & 6 & 5 & 3 & 5 & 6 & 31 & 20.39 & $1 \mathrm{st}$ \\
\hline Urbanization & 3 & 3 & 4 & 4 & 3 & 2 & 19 & 12.50 & 5 th \\
\hline Fuel & 4 & 6 & 5 & 4 & 4 & 5 & 28 & 18.42 & $3 \mathrm{rd}$ \\
\hline
\end{tabular}

Informant consensus factor (ICF) was used to support the data and to see the degree of agreement on each plant reported by informants. The highest value of ICF is 0.71 for diabetics who depict prevalence of diseases in the area and lowest value is for bronchitis $0.21 \%$ (Table 2). In this study, it was demonstrated that Berberis lyceum and Ajuga bracteosa has the highest fidelity level (FL: 100\%) being used to cure diabetic patients while Viola canescens has the lowest FL, 14\% (Table 3). Direct Matrix Ranking (DMR) was performed to assess the multipurpose uses and their impacts on the plant species. The result of the direct matrix ranking showed that Juglan regia stood first in being the most multipurpose medicinal plant, followed by Morus alba, whereas Ricinus comunis was the least (Table 4).The ranking of threatened economic plants was conducted using 10 informants. The results (Table 5) indicated that Aconitum heterophyllum is the most threatened, and Bistorta amplexicaulis the least threatened. Timber mafia/export was the leading threat followed by construction, fuel, grazing and urbanization respectively (Table 6). These facts illustrate that we should not be ignorant of the scenario and, a planned and comprehensibly biodiversity conservation and preservation program with collaboration of national of international nature conservation agencies should be launched immediately.

Collection of fuel wood species kept throughout the year during harsh winter resulting continuous destruction of natural forest and vegetation. Forest resources such as, Cedrus deodara and Pinus wallichiana are disappearing at an alarming rate. Forest department should reintroduce this tree. A number of other medicinal plants like Berberis lyceum, Ajuga bracteosa, Aconitum heterophyllum, Taraxacum offincinale, Bistorta amplexicaule, Saussurea lapa and Jurinea dolomiaea are on the edge of extinction due to over exploitation (Ahmad et al., 2012b). The natural vegetation of the area was badly affected due to high intensity of Earth-quake (7.6 magnitudes) in Oct, 2005 and recent flood August (2010). The studies suggested that indigenous knowledge should be engaged for the conservation of biodiversity and sustainable ecosystem restoration (Ishtiaq et al., 2012). There should be close kinship between conservation scientists with indigenous peoples that attract and encourage their active participation in different activities of biodiversity conservation.

\section{Conclusion and Recommendations}

Dawarian village in Neelum Valley is floristically rich areas need attentions for plants conservation of existing vegetation and reforestation. Plants which are being eradicated, become rare, endangered, and finally diminish from the local population. The people of the area should have an easy access to doctors, so that dependence on the traditional medicinal plants can be minimized. Necessary steps should be taken not only to store the original vegetation but also to improve it. Deforestation is very common, because people have no alternative source of fuel. Therefore, 
if natural gas should be supplied to the area, it will protect the vegetation to large extent.

\section{REFERENCES}

[1] Ahmad, K.S., Kiyani, W.K., Hameed, M., Ahmad, F., and Nawaz, T. 2012a. Floristic diversity and ethnobotany of Senhsa, District Kotli, Azad Jammu \& Kashmir (Pakistan). Pakistan Journal of Botany, 44: 195-201.

[2] Ahmad, K.S., Qureshi, R., Hameed, M., Ahmad, F., and Nawaz, T. 2012b. Conservation assessment and medicinal importance of some plants resources from Sharda, Neelum valley, Azad Jammu and Kashmir. International Journal of Agriculture and Biology, 14: 997-1000

[3] Alexiades, M. 1996. Collecting ethnobotanical data. An introduction to basic concepts and techniques. In: Selected guideline for ethnobotanical research: A Field Manual, pp.58-94. Ali, S.I. and E. Nasir. 1970-2002. Flora of Pakistan, National Herbarium, NARC, Islamabad and Department of Botany, University of Karachi, Karachi. Fasc. No. 1-207.

[4] Ali, H. and Qaiser, M. 2009. The Ethnobotany of Chitral Valley, Pakistan with Particular Reference to Medicinal Plants. Pakistan Journal of Botany, 41(4): 2009-2041.

[5] Ali, S. I. and Qaiser, M. (Eds.). 1993-2009. Flora of Pakistan (Fascicle series), Islamabad, Karachi.

[6] Ali, S.I. and Qaiser, M. 1986. A phytogeographical analysis of the phanerogames of Pakistan and Kashmir. Proc. R. Soc. Edinburg 89B: 89-101.

[7] Ali, S.I. and Qaiser, M. 2001-2008. Flora of Pakistan (Fascicles series), Department of Botany, University of Karachi, Pakistan.

[8] Ali, S.I. and Nasir, Y.J. (Eds.). 1990-1991. Flora of Pakistan (Fascicle series), Islamabad, Karachi.

[9] Balick, M.J. and Cox, P.A. 1996. Plants, people and Culture: Science of Ethnobotany. New York, USA.

[10] Bokhari, A. H. 1994. Ethnobotanical survey and vegetation analysis of Machyara National Park Azad Kashmir, Pakistan. M.Sc. Thesis, University of Azad Kashhmir.

[11] Cotton, C.M. 1996. Ethnobotany: Principles and Applications. John Wiley and Sons, New York, p. 412.

[12] Dar, M.E.U. 2003. Ethnobotanical use of Lawat district Muzaffarabad,Azad Jammu and Kashmir. Asian Journal of Plant Science, 2 (9):680-682.

[13] Hamayun, M., Khan, S.A., Kim, H.Y. and Leechae, I.J 2006. Traditional knowledge and ex-situ conservation of some threatened medicinal Plants of Swat Kohistan. Pakistan Journal of Botany, 38(2): 205-209.
[14] Haq, I. 1983. Medicinal plants. Hamdard Foundation Press, Pakistan.

[15] Ishtiaq, M., Mumtaz, A.S., Hussain, T. and Ghani, A. 2012. Medicinal plant diversity in the flora of Leepa Valley, Muzaffarabad (AJK), Pakistan. African Journal of Biotechnology, 11(13): 3087-3098.

[16] Ishtiaq, M., Hanif, W. and Khan, M.A. 2006. Ethnoveterinary medicinal uses of plants from Samahni Valley District Bhimber, (Azad Kashmir) Pakistan. Asian Journal of Plant Science, 5(2): 390-396.

[17] Ishtiaq, M., Hanif, W., Khan, M.A., Ashraf, M., and Butt, A.M. 2007. An Ethnomedicinal Survey and Documentation of Important Medicinal Folklore Food Phytonyms of Flora of Samahni Valley, (Azad Kashmir) Pakistan. Pakistan Journal of Biological Science, 10(13): 2241-2256.

[18] Khan, M.A., Hussain, M. and Mujtaba, G. 2010. An Ethnobotanical Inventory of Himalayan Region Poonch Valley Azad Kashmir Pakistan. Ethnobotany Research \& Applications., 8:107-123.

[19] Mahmood, A., Qureshi, R. A., Mahmood, A., Sangi, Y., Shaheen, H.M., Ahmad I., and Nawaz, Z. 2011. Ethnobotanicalmsurvey of common medicinal plants used by people of mdistrict Mirpur, AJK, Pakistan. Journal of Medicianal Plants Research, 5(18):4493-4498.

[20] Mohammed, I.C., Khan, M.A., and Hanif, W. 2006. An Ethnomedicinal Inventory of plants used for family planning and sex diseases Treatment in Samahni Valley, Pakistan. Pakistan Journal of Biological Science, 9 (14): 2546-2555.

[21] Nasir, E. and Ali, S.I. (Eds.) 1970-1989. Flora of Pakistan (Fascicle series), Department of Botany,University of Karachi, Pakistan.

[22] Qureshi, R.A., Ghufran, M.A., and Gilani, S.A. 2007. Ethnobotanical studies of selected medicinal plants of Sudhan Gali and Ganga Chotti Hills, district Bagh, Azad Kashmir. Pakistan Journal of Botany, 39(7): 2275-2283.

[23] Qureshi, R. 2004. Floristic and Ethnobotanical Study of Desert Nara Region, Sindh. Department of Botany, Shah Abdul Latif University, Khairpur, Sindh, Pakistan. Ph.D. Thesis, Vol. I: 1-300.

[24] Shinwari, Z.K. 2010. Medicinal plants research in Pakistan. Journal of Medicianal Plants Research, 4(3): 161-176.

[25] Shinwari, Z.K. and Gilani, S.S. 2003. Sustainable harvest of medicinal plants at Bulashbar Nullah, Astore (Northern Pakistan). Journal of Ethnopharmacology., 84: 289-298.

[26] Stewart, R.R. 1972. An Annotated Catalogue of the Vascular Plants of West Pakistan and Kashmir. Fakhri Printing Press, Karachi.

[27] WHO. 2002. World health organization traditional medicine strategy 2002-2005. 